\title{
IBN KHALDUN THOUGHT: A review of al-Muqaddimah Book
}

\author{
Wawan Hernawan \\ UIN Sunan Gunung Jati Bandung \\ Wanha99@yaho.co.id
}

\begin{abstract}
Nowadays Muslim and non-Muslim scholar have no paid exhaustion attention yet onalMuqaddimah book of Ibn Khaldun (1332-1406). Al-Muqaddimah Book is still being studied and debated critically. Actually, this work is still "dazzling" social scientists, anthropologists, theologians, philosophers, historians, and economists even compared with the other great works produced by other classical Muslim scholars. Search for the book of al-Muqaddimah Ibn Khaldun intends to seek and drank authenticity thoughts. It becomes important in the center of issue. We should be wise to this Muslim leader, because it has a big hand in an attempt to find the "authenticity" of Muslim thought. By using the method of historical research, it is obtained: first,for Ibn Khaldun, history is one of the disciplines studied extensively by the nations and generations. Second, the legal history is applicable universally so the truth can be revealed. Third, a historian should study the areas of human life (sociology, anthropology, theology, philosophy, history, and economics) to determine differences between main and general characteristics. Fourth, related to the modern social sciences, undoubtedly Ibn Khaldun is first beginning of sciences. He was a golden bridge for the development of science and the history of modern sociology.
\end{abstract}

Keywords: Daula, Cycle, People, Organization, Dharury

\section{Introduction}

In printed form, al-Muqaddimah emerged in 1858, edit by Etenne Marc Quatremere in Paris. ${ }^{1}$ Ten years later al-Muqaddimah translated into French by W.M de Slane ${ }^{2}$ under the title Les Prolegomenes d'Ibn Khaldun (1862-1868). The presence of that translation is more evocative scientists to know more about the personal Ibn Khaldun and the monumental work. Discourse ofal-Muqaddimah, since that, the scientific journals of various languages began to appear

\footnotetext{
${ }^{1}$ Ahmad Syafi'i Ma'arif, Ibn Khaldun Dalam Pandangan Penulis Barat dan Timur (Jakarta: Gema Insani Press, 1996), 1 .

${ }^{2}$ Ibid.
}

almost endlessly. At the same time, a number of attributes attached to Ibn Khaldun expertise. He is referred to as a philosopher of history, historian, father of sociology, geographers, economists, political scientists, and others. Lenn Evan Goodman $^{3}$ from University of Hawaii appreciated him like Thucydides (455-400 BC) as "Father of History", both considered adherents of cyclical patterns in reading history way. ${ }^{4}$

After Quatremere edition, a century later appeared in English translation by Franz

\footnotetext{
${ }^{3}$ Lenn Evan Goodman, "Ibn Khaldun and Thucydides", In Journal of American Oriental Society, Vol. 92 No. 2 (April-June 1972), 250.
} 
Rosenthal (1958).He is a well-known linguist and philologist. Translation of Rosenthal consists of three volumes totaling 1,425 pages beside foreword, index, and others. This translation is the result of exceptional hard work, though still found a number of criticisms. ${ }^{5}$ It still in English translation, the second edition published in 1967. Theses expressed by Ibn Khaldun reinforce scholar interest to continue studying. However, a natural in scientific discourse, there are pro and contrast attitudes on ideas or findings of a scientist, not an exception to the Ibn Khaldun and theses were put forward. The pro puts Ibn Khaldun in a very high position, as an encyclopedic thinker who was not much appeared in history. ${ }^{6}$ In perspective of utilitarian function of religion, A. Pitirim Sorokin had put Ibn Khaldun parallel to Plato, Aristotle, Giambattista Vico, St.Thomas Aquinas as an idealistic thinkers. ${ }^{7}$ As for the cons, as shown in article of P. Von Sivers, alMuqaddimah, he wrote, though well known, “... is a curiusly twisted, grand misconception of the historical process. ${ }^{8}$ Both extremes present the third moderate, as read in the works of Fu'ad Baali, Society, State, and Urbanism: Ibn Khaldun's Sociological Thought. ${ }^{9}$ Assessment clashing of Ibn Khaldun and his ideas are one indication of the fact, that al-Muqaddimah book still have not worn for discussion among scientists.

\footnotetext{
${ }^{4}$ Related to this, Ahmad Syafi'i Ma'arif comparedalMuqaddimahwith Thucydides work, History of the Peloponnesian War. He concluded that, both have similarities in historian study approach. Besides, they developed critical thinking in writing history; it is different with traditional historian approach. See Ahmad Syafi'i Ma'arif.

${ }^{5}$ See, Ibn Khaldun, The Muqaddimah: An Introduction to History, translateby Franz Rosenthal in 3 Vol. London: Routledge \& Kegan Paul, 1967, I:XXIV. See, Ahmad Syafi'i Ma'arif.

${ }^{6}$ A.J. Toynbee, A Study of History, 12 jilid (London: Oxford University Press, 1945), 322.

${ }^{7}$ Pitirim A. Sorokin, Sociological Theories of Today (New York and London: Harper \& Row, 1966), 308.
}

\section{Who is Ibn Khaldun?}

Ibn Khaldun has a full name waliy ad-Din Abu Zaid Abdurrahman ibn Muhammad ibn Khaldun al-Hadrami al-Ishbili. ${ }^{10}$ He was born in Tunisia on May 27, 1332. Khaldun has nick name Abdurrahman. In his family he is called Abu Zaid associated with the name of his eldest son. While, waliy ad-Din is given as honor and greatness of the king of Egypt, when he was appointed Chairperson of Justice in Egypt. ${ }^{11}$

Ibn Khaldun's ancestors who first came to Tunisia is al-Hasan ibn Muhammad (fourth grand father Ibn Khaldun). ${ }^{12}$ After that, it followed by other brothers, like Abu Bakar Muhammad ibn Abu Bakar Muhammad, and others. Ibn Khaldun's grand father is many occupy important positions in the government at that time. While Abu Abd Allah Muhammad (Ibn Khaldun's father) was not attracted to positions in government. He was more interested in the field of science and education, and became known as an expert of fiqh knowledge. Abu Abdillah Muhammad died in 1349. He left several children, Wali ad-Din Abu Zaid 'Abdurrahman (Ibn Khaldun), Umar Musa, Yahya and Muhammad. At the time, Ibn Khaldun was 18 years old. ${ }^{13}$

Ibn Khaldun was educated in religion, language, logic and philosophy. The main teacher was his own father. ${ }^{14}$ Besides, Ibn Khaldun also memorize Al-Quran, studying physics and

${ }^{8}$ P. Von Sivers, "Back to Nature: The Agrarian Foundations of Society According to Ibn Khaldun" in Arabica, Vol. 27 No. 1 (Feb. 1980). 89.

${ }^{9} \mathrm{Fu}$ 'ad Baali, Society, State, and Urbanism: Ibn Khaldun's Sociological Thought (New York: State University of New York Press, 1988), viii.

${ }^{10}$ Ahmad Syafi'i Ma'arif, 11.

${ }^{11}$ Yusuf Kertanegara, "Ibn Khaldun”in http:// ucup33.student.umm.ac.id-/2010/08/26/Ibn-khaldun-2/. retrieved, April 5, 2015 on 03.17p.m.

${ }^{12}$ Bensalem Himmish, Ibn Khaldun Sang Mahaguru, Novel, terjemahan Ridwan (Tangerang: Lentera Hati, 2010), 522. ${ }^{13}$ Juwariyah, "Ibn Khaldun Dan Pemikirannya Tentang Pendidikan"in http://uin-suka-.info/ejurnal/index. php?option $=$ com_content\&task=view\&id=100\&Itemid $=52$. retrieved, March31,2015, pukul 7.47 p.m. 
mathematics from great scholars and intellectuals of his time. They are Muhammad ibn Sa'd Burral al-Ansari, Muhammad ibn Abdissalam, Muhammad ibn 'Abd muhaimin al-Hadrami, and Abu Abdillah Muhammad ibn Ibrahim al-Abilli. From the teachers, Ibn Khaldun get various kinds of knowledge. ${ }^{15}$

In 1349, after both of his parents died, Ibn Khaldun decided to move to Morocco. But it is prevented by her brother. New in 1354, he carried out his intention. ${ }^{16}$ In Morocco, he gets a chance to complete his higher education. During his studies, there are four science practiced in depth, namely: First, Arabic language consists of: Nahwu, shorof, balaghoh, khitabah and literature. Second, shari'ah science consists of: Fiqh (Maliki), tafsir, hadith, fiqh and science of the Qur' an. Third, 'aqliyah (philosophical sciences) consists of: philosophy, mantiq, physics, mathematics, astronomy, music, and history. Fourth, state science consisting of: science of administration, organization, economics, and politics. ${ }^{17}$

Entering of 20 years old, Ibn Khaldun became interested in politics. Because of his capacity, he was appointed Secretary of the Sultan. ${ }^{18}$ Position Secretary Sultan is no longer held, because in 1357, he was involved in the conspiracy with Amir to overthrow Amir Abu Abdullah Muhammad. In that year he was arrested and imprisoned. ${ }^{19}$ Not long after he was released. In the same year, after Sultan dies and power seized by Al-Mansur ibn Sulayman from his minister Al-Hasan, Ibn Khaldun joined with AlMansur and was appointed as his secretary. ${ }^{20}$

\footnotetext{
${ }^{14}$ Laila Amra, "Ibn Khaldun: Ilmuwan Besar dari Tunisia"in http://www.-gaulislam.com/Ibn-khaldunilmuwan-besar-dari-tunisia. Retrieved Maret 31, 2015, on 7.50 p.m.

${ }^{15}$ Juwariyah.

${ }^{16}$ Ibid.

${ }^{17}$ Ibid.

${ }^{18}$ Zainab Al-Khudairi, Filsafat Sejarah Ibn Khaldun (Bandung: Pustaka), 11.

${ }^{19}$ Ibid.

${ }^{20}$ Ibid., 12 .
}

On his journey, because there is a mismatch, Ibn Khaldun soon became secretary ofAl-Mansur. He then left and in cooperation with Abu Salim. At the time of Abu Salim throne, Ibn Khaldun was again appointed as secretary. ${ }^{21}$ After two years of Ibn Khaldun was appointed to the Supreme Court. This is where he began to show exceptional achievement. But it did not last long, 1361 rebellion among the royal family. At that time, Ibn Khaldun was soon stripped of office bears. $^{22}$

Apparently, Ibn Khaldun did not survive to continue to wrestle in politics. He was back in science where he long left behind. For that, he turned to Banu Arif ${ }^{23}$ with his family. In Banu Arif region, Ibn Khaldun and his family feel calm and peaceful life, far from political hypocrisy. In composure, Ibn Khaldun shed all the experience and vagaries of life. He began to turn his life journey of a political adventurer to develop science. This is where he started to compose "his magnum opus", al-Muqaddimah. ${ }^{24}$

During four years of living in Banu Arif, Ibn Khaldun also compiled the history of the magnitude of al-'Ibar. ${ }^{25}$ However, because lack of reference, he went to Tunisia, and he completed his work there. Apparently Ibn Khaldun tranquility interrupted again when Sultan invited him to accompany crushing the vandals. He ignored Sultan invitation. He is saturated with bustle of politics. He then moved to Egypt. In Egypt, Ibn Khaldun was greeted warmly. Scholar scientist is already familiar, because the works have been scattered there. As the new, Ibn Khaldun was immediately given two important positions, namely as high court judges and a professor at Al-Azhar university. ${ }^{26}$

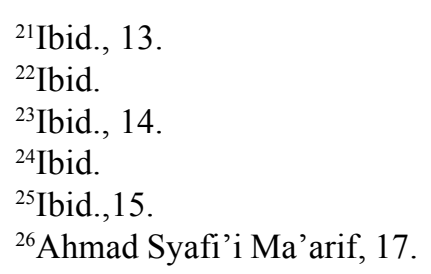


After a long period work for science and serve for North Africa and Andalusia, Ibn Khaldun died on March 17, 1406 at the age of 76 years. He was buried in Sufi Babul Nasr in Cairo. ${ }^{27}$

\section{Ibn Khaldun Work}

An interesting and bizarre in the history of writing, one becomes famous through the introduction of his writing. He is Ibn Khaldun. He became appreciated, because al-Muqaddimah . Al-Muqaddimah, it is not more than introduction of the article intact, al- 'Ibar book. Weirdness was increasingly felt, because of al-Muqaddimah, he glorified in the intellectual history world. AlMuqaddimah, in turn, becomes a monumental work of all time who has made scholars in the West and East so admired. Windellband said Ibn Khaldun as "magic figure completely separated, both from the past and the future". ${ }^{28}$

In the writing world, Ibn Khaldun actually already started his career since his young age. He loved this area when he was a student and continued during active in politics and government. The results of his works are wellknown are: First, the Book Muqaddimah ${ }^{29}$, which is an 'Ibar, which consists of Muqaddimah (introduction). Long introductory book is the core of the whole matter. Through the introduction of the book, Ibn Khaldun's name to be so remembered. The central theme of alMuqaddimah are social phenomena and history.

Secondly, Kitab al-'Ibar wa Diwan almubtada'wa al-Khabar fi Ayyam al-'Arab al'Ajam wa al-Barbar man Asharuhum min dzawi as-Sulthani al-'Akbar ${ }^{30}$ (Book of Lessons and History Archive of Period Beginning and the End Times that include Political Events Regarding the Arabs, non-Arabs and Berbers, and Kings During the Great with Them). This book became known

\footnotetext{
${ }^{27}$ Ibid., 23.

${ }^{28}$ Juwariyah.

${ }^{29}$ Zainab Al-Khudairi, 28.

${ }^{30}$ Ibid., 22.
}

by the name of Kitab 'Ibar. This book consists of three books: The first book, Kitab Muqaddimah, or the first volume which contains about: Society and characteristics are essential, namely government, power, livelihood, skills and knowledge with all causes and reasons. The second book consists of four volumes, namely: the second volume, third, fourth, and fifth, which describes the history of Arab nation, their generations and dynasties. In addition it also contains a review of nations and the well-known contemporary country with them, such as Syrian, Persians, Jews (Israel), Greek, Roman, Turkish and Franks (Europeans). Then, the third book consists of two volumes, namely: the sixth and seventh volume, which contains the history of language of Berbers and Zanata that are part of them, particularly the kingdoms and countries of the Maghreb (North Africa). ${ }^{31}$

Third, Kitab al-Ta'rif bi Ibn Khaldun wa Rihlatuhu Syarqon Ghorban or called al-Ta'rif. ${ }^{32}$ This book by Westerners called autobiography. This book is the last part of Kitab al-'Ibar which contains several chapters about Ibn Khaldun life. He wrote his autobiography systematically using the scientific method, as separate chapters, but interconnected with each other.

\section{Ideas/Thoughts of Ibn Khaldun}

\section{A. State Origin (Daulah)}

According to Ibn Khaldun, human beings were created as political or social, who always need someone to sustain life. Therefore, their life in community and social organization are a necessity (dharury). ${ }^{33}$ This argument seems similar to the opinion of Al-Mawardi and Abi Rabi'. Furthermore, according to Ibn Khaldun, humans just might survive to live with food. Moderate to meet minimal food in one day

\footnotetext{
${ }^{31}$ Ibid., 22-28.

${ }^{32}$ Ibid., 39.

${ }^{33}$ Ahmadie Thoha, Muqaddimah Ibn Khaldun (Jakarta: Pustaka Pirdaus, 2011), 71.
} 
requires a lot of work. As an example, a grain of wheat to be a piece of bread requires a long process. Grains of wheat to be ground first then burned before it is ready to eat. For all it is also necessary tools and cooperation with carpenter or iron. Likewise wheat, it is not necessarily exist, but it takes a farmer. It's meant, according to Ibn Khaldun, a human in order to survive with the food needs of other human beings. ${ }^{34}$

On the other hand, according to Ibn Khaldun, man needs help in defense against the threat of danger. This is because when Allah created the universe has divided power between living creatures. Even, many animals have more power than human.Aggressive character according to Ibn Khaldun, is something naturally for every creature. Therefore, Allah swt gave everyone part of special body to defend him. The human being is given mind to think and two hands. ${ }^{35}$ Through mind and hands, according to Ibn Khaldun, humans can survive as farm or undertake other activities to sustain life. However, humanneed helping from others, so that civil society organizations is also an obligatory. Without organization, human existence would not be complete. God's will to fill the world with mankind and let it breed as caliph would not be accomplished. ${ }^{36}$

After a community organization formed, that is civilization. Society needs someone who can influence and separators are acting as a mediator between community members. That's according to Ibn Khaldun, because humans have an aggressive and unfair character, so by mind and hands are given by God did not allow it to defend himself from attack another human being, because every human being has a mind and hands as well. Therefore, they need something to counter act the aggressive nature of man to the other. Humans in question is someone from the

\footnotetext{
${ }^{34}$ Ibid., 71-72.

${ }^{35}$ Ibid., 72.

${ }^{36}$ Ibid., 72-73
}

community himself, one whose influence on society members, it has the authority and power over them as controller/Wazi'(الوازع). Thus, there will be no society who attacked other community. The need for someone who has the authority and control is then increased. Supported by a sense of togetherness, leader (rais) to regulate and mediate can not work alone, so it requires strong and loyal soldiers, Prime Minister, as well as other helpers. That's according to Ibn Khaldun, the process of formation of a Dynasty (daulah) or kingdom (mulk). ${ }^{37}$

\section{B. Sociological Society: Bedouin civilization, man city, and Social Solidarity}

Besides the ideas/thoughts that have been described in previous discussion, Ibn Khaldun argues, that there are other factors forming the State (daulah), namely 'asabiyyah (العصبية). 'Asabiyyah according to Ibn Khaldun implies Group feeling, groups solidarity, fanaticism of tribalism, nationalism, or social sentiments. ${ }^{38}$ By 'asabiyyah, according to Ibn Khaldun, to foster love and affection of a man to relatives or neighbors when oneof them being treated unfairly or harmed, Ibn Khaldun in this case raises two fundamental social categories, namely Badawah (بداوة) (Rural communities, primitive society, or desert areas) and hadara (حضارة) (Life of the city, a civilized society). ${ }^{39}$ Both are a natural phenomenon and undoubtedly (dharury).

For Ibn Khaldun, there are many city dwellers living well. They are accustomed to living in luxury and more debauched. Their souls have been contaminated by various kinds of reprehensible morals. While people Badawah, although have same problems in the world, but it is still in limits necessity, not in luxury, lust and pleasure. ${ }^{40}$ Regional fertile influence on religious

\footnotetext{
${ }^{37}$ Ibid., 74.

${ }^{38}$ Ibid., 57.

${ }^{39}$ Ibid., 395.

${ }^{40}$ Ibid., 101-102.
} 
matters. Bedouins who live simpler than those cities live starve leaving luxury food is better in religion than people who live in luxury and excess. Devout people few live in cities, because the city has been filled with violence and indifference (individualist attitudes). Therefore, according to Ibn Khaldun, the majority of people who live in the desert are those who prefer spirituality and ascetic. Bedouin is bolder than city dwellers. Because of the city's population is more lazy and liked easier (very practical). They dissolve in pleasure and luxury (hedonic). They entrust themselves and property security affairs to the ruler. While the Bedou in live isolate from society. They live wild in places far outside the city and never gain control of the army. For that, they themselves defend themselves and do not ask for help to others. ${ }^{41}$

To survive, Ibn Khaldun says rural communities must have sentiment group ('asabiyya) which is a driving force in the course of human history, generating a clan. Clan has 'strong ashabiyyah may develop into a country. Leadership qualities are always had by those who have social solidarity. Each tribe is usually tied to the descendants of a specific nature (typical) or public ('am). Solidarity in special clan is more ingrained than general solidarity. Therefore, according to Ibn Khaldun, the lead can only be carried out with power. Social solidarity which is owned by the leader must be stronger than the other. Thus, he will gain power and can lead people to perfection. Social solidarity becomes a power requirement. ${ }^{42}$

To lead, according to Ibn Khaldun, should havea social solidarity on every individual. If solidarity of each individual recognize benefits of leader social solidarity, it consequence must follow and obedient to the leader. Wild Nations are more capable power than other. Desert life is a courage source. One is not an exaggeration when

\footnotetext{
${ }^{41}$ Ibid., 103-104.

${ }^{42}$ Ibid., 104.
}

it is said that the wild tribes bolder than other. According to Ibn Khaldun, they are more able to have power and plunder everything that was in grip of another nation. It is caused, according to Ibn Khaldun, the power possessed by the courage and hardness. If one of these parties is greater accustomed to living in desert and more wild, he would be easier to have power than other groups. ${ }^{43}$

Ibn Khaldun thought, in this case, is not surprising; he was doing research on Arab society and Berbers in which undergoing difficult life in desert. The purpose of solidarity, according to Ibn Khaldun, is sovereign. ${ }^{44}$ Because of social solidarity is unites goals, defend against, and defeat of enemy. Indeed social solidarity gain sovereignty over its class, according to Ibn Khaldun, he would seek solidarity with other groups who are not related to him. If social solidarity is equivalent, more Ibn Khaldun, people who are under it would be comparable. Furthermore, if social solidarity can conquer others solidarity, then they will combine to lead the higher goal of sovereignty. ${ }^{45}$ Finally, according to Ibn Khaldun, if a state was old and his superiors which consisted of social solidarity has not longer support it, the new social solidarity will seize the country's sovereignty. Thus, if a state was old, then it needs others solidarity. In such situation, the state will take the strong social solidarity followers to sovereignty and serve as a tool to support a country. That is what Ibn Khaldun said which occurred on the Turkish people who go to the sovereignty of Bani Abbas. ${ }^{46}$

However, according to Ibn Khaldun, the problems achieving sovereignty is a luxury. The greater luxury and pleasure, they will be closer to destruction, it is not to obtain sovereignty. Luxury has destroyed and eliminated social solidarity. If a country is destroyed, then it will be replaced by

\footnotetext{
${ }^{43}$ Ibid., 165.

${ }^{44}$ Ibid., 166.

${ }^{45}$ Ibid., 167.

${ }^{46}$ Ibid.
} 
people who have solidarity in social solidarity. ${ }^{47}$ According to Ibn Khaldun, if a nation was wild, then sovereignty will be very broad. Because that nation is better to gain power and hold full control in the conquest of other groups. ${ }^{48}$

The final goal of social solidarity ('asabiyya) according to Ibn Khaldun is sovereignty. 'Asabiyya is present in human nature which is essentially an assortment. It may be a blood bond, equal divinity, adjacent or neighboring residence, partnership or alliance, or the relationship between protectors and protected. ${ }^{49}$ Special Arabs, according to Ibn Khaldun, equal divinity makes them managed to establish Dynasty. Because according to him, Arab is nation that unwilling to subdue one to another, rude, arrogant, ambitious, and each wants to be the leader. The exist of 'Asabiyya is only 'asabiyya tribal/qabilah which does not allow establishing a dynasty, because of their nature. Because of religion brought by Prophet they can eventually be united and controlled. ${ }^{50}$ But according to Ibn Khaldun further, that religious motivation only is not enough, so it is still needed group solidarity ('asabiyya). ${ }^{51}$

Religion can streng then solidarity group and increase its value. However, it still needs other motivations present on out of Religion. ${ }^{52}$ Homogeneity said Ibn Khaldun was also influential to create a great dynasty. It is rarely a dynasty can stand in areas with various tribes. Each tribe in such circumstances has interests, aspirations, and different views. So it is likely to form a great dynasty is difficult. According to Ibn Khaldun, it is only with Homogenates will cause strong solidarity to create a great dynasty. Relate to 'ashabiyyah, Ibn Khaldun judge, a king should

\footnotetext{
${ }^{47}$ Ibid., 168.

${ }^{48}$ Ibid.

${ }^{49}$ Ibid., 151-152.

${ }^{50}$ Ibid., 182.

${ }^{51}$ Ibid., 187-188.

${ }^{52}$ Ibid., 192.
}

come from the most dominant group.To control of a country, maintain order and protect the country from enemy threats both from outside and from inside, a king needs support and loyalty from his society. According to Ibn Khaldun, it can only be realized if it originated from the dominant group.

\section{Khalifah, Imamah, Sulthanah}

Khilafah according to Ibn Khaldun is a government that is based religion, govern citizen in accordance with God's instructions both temporal and hereafter. Government is based on religion, according to Ibn Khaldun, it called Khalifah, Imamah, or sulthanah. ${ }^{53}$ The leaders called Khalifah, Imam, or Sulthan. ${ }^{54}$ Khilafah is successor of the Prophet Muhammad, with the task of maintaining religion and running the leadership in world. According to Ibn Khaldun Imamat institution is mandatory based on religious law as evidenced by constituted $\mathrm{Abu}$ Bakar as caliph.But there is also an opinion, Imamah is mandatory because mind sees human need a social organization. Although it is mandatory, the legal is fardhu kifayah. ${ }^{55}$

Ibn Khaldun's divided five terms for the Khalifah, Imam, or Sulthan, namely: ${ }^{56}$ First, have knowledge. Secondly, have fair character. Third, have ability. Fourth, healthy senses and body. Fifth, descendants of Quraysh. Based on the theory of 'ashabiyah', Ibn Khaldun has similar thought with earlier Muslim thinkers about virtue descendant of Qurais. He argues that Qurais is famous leader, original, and performing of Bani Mudar. They have much numbers, strong solidarity group, and with elegance, Qurais have a high prestige. One that is not so surprising, according to Ibn Khaldun, if the Islamic leadership entrusted to them. Arabs also recognize the reality

\footnotetext{
${ }^{53}$ Ibid., 233-234.

${ }^{54}$ Ibid., 234-235.

${ }^{55}$ Ibid., 237.

${ }^{56}$ Ibid., 238-239.
} 
of their authority, as well as their respect for excellence of Qurais. If the leadership is held by another tribe, it would happen insubordination and destruction. Actually, the Prophet Muhammad wants unity, solidarity and fraternity. ${ }^{57}$ However, according to Ibn Khaldun, it should not be interpreted, that the leadership was monopolized by the Qurais tribe, or a descendant of Qurais requirement takes precedence over ability. It is only based on dignity and high solidarity for Qurais at the time. so when the Qurais tribe was not authoritative, or there are no other tribes who have 'ashabiyyah and high authority, the leadership of Qurais could no longer. Thus, the leadership can move to ethnic or other groups who have authority, solidarity, and a higher ability. ${ }^{58}$

\section{Models of Government}

Ibn Khaldun argues that there are three Models of government. First, natural rule (siyasah thabi'iyah), the government brought the community in accordance with the purpose of lust. ${ }^{59}$ According to Ibn Khaldun, if a king rules the kingdom (mulk) follow the will and desires and do not pay attention to societyneed. Society consequently will be difficult to obey the king. A king who follows his own desires and willing, it will make terror, oppression and anarchy. These Kingdoms now a days, it is like authoritarian, individualistic, autocratic, or unconstitutional. Second, a government based on reason (siyasah 'aqliyah), ${ }^{60}$ it is government brought in accordance with the ratio of people in achieving the benefit of the world and prevent pernicious. Government is based on laws made by scholars. This government is as touted, but on the other hand criticized. This government today is same as Republican government, or kingdom institutional that can deliver justice to a certain

\footnotetext{
${ }^{57}$ Ibid., 239-243.

${ }^{58}$ Ibid., 243.

${ }^{59}$ Ibid., 232.

${ }^{60}$ Ibid., 233.
}

extent. Third, government based on religion (siyasa diniyyah), ${ }^{61}$ namely government is bring society in accordance with the guidance of religion, both temporally and eternity. According to Ibn Khaldun, this is the best governance model, because the law derived from religious teachings to be guaranteed is not only security and prosperity in the world, but also in the hereafter. According to Ibn Khaldun, Khalifah is a successor of the Prophet in preserving the religious and prosperous of society life. Imam is as a leader like the prayer to be followed by his congregation. From the division of government above, it appears, that Ibn Khaldun did not look at the personal side, or on the Priest's office itself, but on the functional significance of his faith. According to Ibn Khaldun, the substance of any government is the law that describes the character of government system.

\section{E. Rising and Fallof a Civilization}

Based on the theory of 'ashabiyyah, Ibn Khaldun made a theory about the stages of rising and fall of a country or a civilization into five stages. First, a successful phase or consolidation phase. According to Ibn Khaldun, the state authorities supported by the community (ashabiyyah) toppled the sovereignty of the previous dynasty. ${ }^{62}$ Second, the stage of tyranny. This stage ruler run riot on his people. ${ }^{63}$ At this stage, according to Ibn Khaldun, the man who led the country collect and reproduce followers. Ruler closes the door for those who wish to participate in his government. All attention devoted to the interests of retaining and winning family. Third, prosperous stage. ${ }^{64}$ This stage is sovereignty has enjoyed. All attention ruler devoted to the effort to build the country. Fourth, the stage of contentment, calm and peaceful. ${ }^{65} \mathrm{At}$

\footnotetext{
${ }^{61}$ Ibid.

${ }^{62}$ Ibid., 214-215.

${ }^{63}$ Ibid., 215.

${ }^{64}$ Ibid.

${ }^{65}$ Ibid., 216.
} 
this stage, the authorities were satisfied with everything that has been built predecessors. Fifth, live stage wasteful and redundant. ${ }^{66}$ At this stage, the ruler became destroyer legacy of its predecessor, satisfying lust and pleasure. At this stage, the country just waiting for destruction.

From these stages, according to Ibn Khaldun, led three generations, they are: ${ }^{67}$ First, Builders Generation, is with all its simplicity and solidarity subordinate to the power of authority supports. Secondly, Lovers Generation, those who benefited economically and politically in power system that is not alive to interest of state. Third, Avalanche and Broken Generation, There is no emotional relationship with the country. They can do what ever they like regardless of state condition. If a state has reached on the third generation, the collapse of the state has been as sunnatullah already on the doorstep. According to Ibn Khaldun, this process lasted about a century.

Ibn Khaldun also explained that a great civilization started from the people who have been hammered by a hard life, poverty, and full of struggle. The desire to live prosperous and free from distress coupled with 'ashabiyyah theyattempt to achieve their goals with hard struggle. The dreams will be achieved present a new civilization. The emergence of a new civilization is usually followed by decline of other civilization. The stages above then repeated again, and so it went on so. This theory is known as Cycle Theory. ${ }^{68}$

\section{Social history of Ibn Khaldun}

History records, during the Middle Ages the Church and the Gospel expert dominated European thought. ${ }^{69}$ While the thinkers of Europe is still struggling in search of human nature, which

\footnotetext{
${ }^{66}$ Ibid.

${ }^{67}$ Ibid., 208-209.

${ }^{68}$ Fu'ad Baali, 70; see, Ahmad Syafi'i Ma'arif, 35.

${ }^{69}$ Simon Petrus L. Tjahyadi, Petualangan Intelektual Konfrontasi dengan Para Filsuf Dari Zaman Yunani Hingga Zaman Modern (Yogyakarta: Kanisius, 2004), 102.
}

is about the question of human origins and cultural development. ${ }^{70}$ They answered questions with faith (trust). They put forward the idea that the existence of human beings and all human differences are God's creation. That answer is very theological in spite of thinking openness compared with the previous period, it is the Dark Age. ${ }^{71}$ On the other hand, the factors influenced European thought is the effect of their exploration into the world of the East. ${ }^{72}$ They - Europe explorer - seeking riches in a new land that provides an overview gambling about exotic culture that they encountered on their adventure in Asia, Africa, and America. However, these explorers did not understand the local languages which successfully conquered. Although, they did systematic research, it occurred shortly and the results are limited..$^{73}$

In $14^{\text {th }}$ century, Ibn Khaldun wrote a universal history which reveals a remarkable about the ability of learning and an unusual ability. ${ }^{74} \mathrm{He}$ arranged general theory of computation political and social development over the centuries. He is seen as the only Muslim historians who suggest social and economic reasons for history change. His thinking then, the strong suspicion, inspired Western thinker was introduced in 19th century.

In Al-Muqaddimah, ${ }^{75}$ Ibn Khaldun explains that history is a record of human society or world civilization; about the changes occurred; about human nature; like wildness, hospitality, solidarity groups, revolutions, and rebellions one group to the other group that effected to emergence of kingdoms and countries with

\footnotetext{
${ }^{70}$ Ibid.

${ }^{71}$ Muhammad Quthb, Perlukah Menulis Ulang Sejarah Islam? (Jakarta: Gema Insani Press, 1995), 97.

${ }^{72}$ Agung Deha, "Sketsa Pemikiran Ibn Khaldun" inhttp:// bukukuno.blogspot.com/-2008/06/-sketsa-pemikiran-ibnkhaldun.html. Retrieved, Maret 24, 2011, on 04.03 a.m

${ }^{73}$ Ibid.

${ }^{74}$ Laila Amra.

${ }^{75}$ Zainab Al-Khudairi, 28-32.
} 
varying levels. History also notes about various activities and position, both the needs of life and their activities in science and industry, as well as any changes that occur in society. These are in line with the definition of universal history ${ }^{76}$ that need an understanding of the whole of human experience totally in past to view differences messages that are useful for their future. Two issues dominate universal history writing: ${ }^{77} \mathrm{First}$, availability of material quantity and languages diversity in which is written 'imply' that universal history takes collective work or become second hand history. Second, selection principle associated with selection studies to establish appropriate taxonomic history. These units are geographically, for example: continent, period, development stage or structure, important events, interconnected, it may communication, the struggle for world power, or the development of the world economic system, civilization or culture, empire and nation states, or elected community. Writing universal history has begun Ibn Khaldun, followed by Western historians or historians of West Asia.

In the book of al-Muqaddimah, Ibn Khaldun confirms, that the study of history should go through critical tests. ${ }^{78}$ According to him, there are at least seven fundamental weaknesses in history writing: (1) partiality to opinions and certain sources; (2) too believed in the news history expert; (3) failed to catch the purposes of what is seen and heard and to submit a report on the basis of conjecture and estimates; (4) estimates that have no basis (to the source); (5) ignorance in fact match with actual incident; (6) many people exasperation to get closer to his officials and those who influence by praise and flattering and say good thing about them, and (7) ignorance about the nature of cultural situation. ${ }^{79}$

\footnotetext{
${ }^{76}$ Agung Deha.

${ }^{77}$ Ibid.

${ }^{78}$ Ahmad Syafi'i Ma'arif, 25.

${ }^{79}$ Ibid.
}

Ibn Khaldun though about this critical history is the underlying idea of modern European thought. However, Jean Bodin (1530-1596), Jean Mabillon (1632-1707), Berthold George Niebur (1776-1831), until Leopold von Ranke (17951886), read or not al-Muqadimmah book, the content of their idea are in line with Ibn Kaldun thought. ${ }^{80}$

From here, it is understood, that Ibn Khaldun was an exception. He was not the only thinker who always thinks about abstract things, but thoughts come from the land where it rests. Understanding Ibn Khaldun though as well as understand the thinking of Muslims who dared to criticize a nation. Especially a very rationalist thought, but it did not lose taste and faith to Allah swt.

Arnold J. Toynbee, ${ }^{81}$ historians from the UK, assessing the ability of the thought and works of Ibn Khaldun can be aligned with Thucydides and Machiavelli. Ibn Khaldun was the foundation of history philosophy and sociology. Charles Issawi ${ }^{82}$ in An Arab Philosophy of History, said that Ibn Khaldun was the first scholar who mention clearly and applied a basic of sociology principles. One of the principles argued by Ibn Khaldun about social sciences is "society is not static, the forms of social change and develop."

Ibn Khaldun thought has a great influence on Western scientists long before August Comte, a thinker who greatly contributed to western positivism tradition. ${ }^{83}$ Research method has been mentioned by Ibn Khaldun. In its methodology, Ibn Khaldun put empirical data, theoretical verification, testing hypotheses, and methods of observation. Those are the fundamental basis of western scientific research and world today. ${ }^{84}$

\footnotetext{
${ }^{80}$ Toto Suharto, Epistemologi Sejarah Kritis Ibnu Khaldun (Yogyakarta: Fajar Pustaka Baru, 2003), 112.

${ }^{81}$ A.J. Toynbee, 325-326.

${ }^{82}$ Charles Issawi, An Arab Philosophy of Hirtory: Selections from the Prolegomena of Ibn Khaldun of Tunis (1332-1406) (London: John Murray, 1950), 7; see, Ahmad Syafi'i Ma'arif, 48.

${ }^{83}$ Ibid., 54.

${ }^{84}$ Ibid., 46.
} 
Muhammad Abdullah Enan also stated, Ibn Khaldun in his thought process experience a unique mixture, which is between two contradictory figures, Al-Ghazali and Ibn Rusyd. ${ }^{85}$ Al-Ghazali and Ibn Rusyd are contrary in philosophy. Ibn Rusyd was a faithful follower of Aristotle. Meanwhile, Al-Ghazali was a staunch opponent of Aristotle's philosophy. Ibn Khaldun was a follower of Al-Ghazali in enmity against the logic of Aristotle, as well as followers of Ibn Rusyd in his efforts to influence partisian. ${ }^{86}$

Ibn Khaldun was the only Muslim scholars at that time aware the importance of presumption and category in thinking to resolve intellectual debates. Strong suspicion, Ibn Khaldun build create a new realistic logic, as an attempt to replace logic idealistic of Aristotle patterned paternalistic-absolutistic-spiritualistic. While realistic logic of Ibn Khaldun patterned relativistic-temporalistic-materialistic. With this mindset, Ibn Khaldun observed and analyzed social phenomena and their history, which ultimately created a modern social theory. ${ }^{87}$

\section{Conclusion}

For Ibn Khaldun, history is one of extensive disciplines studied by the nations and generations. The nature of history included the sense of observation and attempt to search the truth, in-depth information about the cause and origin of the object, as well as knowledge of the substance, essence, and pathogenesis of occurrence an event. History has an established method. It is started by heuristics, criticism, interpretation and historiography, as well as the noble aims. History makes man aware of the earlier nations, as a reflection of the current condition of the nation. History is the wheel of human life. It will be always repeated.

\footnotetext{
${ }^{85}$ Muhammad Abdullah Enan, Ibnu Khaldun: His Life and Work (New Delhi: Kitab Bhavan, 1979), 7.

${ }^{86}$ Ibid.

${ }^{87}$ Juwariyah.
}

Concerning the truth of history, Ibn Khaldun argues, that the history of law applicable universally, so the truth can be revealed. To determine the right or wrong of a history is based on the possibility and impossibility. A historian must study the areas of human life (especially cultural anthropology) to determine the difference of basic and general characteristics. Guidelines for stating the truth of history is by using a method that can be demonstrated and recognized by community in order far from errors. This is a testing tool for a historian who wants to get an explanation about history truth.

Therefore, generally, Al-Muqaddimah is organized into three main parts: first, historiography issue. In this regard, Ibn Khaldun explained about mistakes of Arab-Muslim historians. Secondly, culture science issue. For Ibn Khaldun, culture science is the basis of historian understanding. Third, Institutions and Islamic sciences in 14th century. Although it just as an introduction of his book entitled $\mathrm{Al}$ - 'Ibar, in fact Al-Muqaddimah is more illustrious. The entire theory of Ibn Khaldun's about social sciences, culture, and history contained in preface of this book. Related to modern social sciences, undoubtedly Ibn Khaldun is the beginner of sciences. From several studies above, consolidating his position, that his thought precedes Niccolo Machiavelli, Auguste Comte, and others, and become as a bridge for the development history science and modern sociology.

\section{BIBLIOGRAPHY}

A. Ali, Mukti. Ibn Khaldun dan Asal-Usul Sosiologinya. Yogyakarta: Yayasan Nida, 1970.

Agung Deha. "Sketsa Pemikiran Ibn Khaldun" dalam http://bukukuno. blogspot.com/ 2008/06/sketsa-pemikiran-ibn-khaldun.- 
html. Diakses tanggal 24 Maret 2015, pukul 04.03 WIB.

Ahmad Syafi'iMa'arif. Ibn Khaldun dalam Pandangan Penulis Barat dan Timur. Jakarta: Gema Insani Press, 1996.

Baali, Fu'ad . Society, State, and Urbanism: Ibn Khaldun's Sociological Thought. New York: State University of New York Press, 1988.

Enan, Muhammad Abdullah. Ibn Khaldun: His Life and Work. New Delhi: Kitab Bhavan, 1979.

Goodman, Lenn Evan. "Ibn Khaldun and Thucydides". In Journal of American Oriental Society. Vol. 92 No. 2 (1972).

Himmish, Bensalem. Ibn Khaldun Sang Mahaguru. Novel. Terj. Ridwan. Tangerang: Lentera Hati, 2010.

Issawi, Charles. An Arab Philosophy of Hirtory: Selections from the Prolegomena of Ibn Khaldun of Tunis (1332-1406). London: John Murray, 1950.

Juwariyah. "Ibn Khaldun dan Pemikirannya

Tentang Pendidikan" dalam http://uinsuka-.info/ejurnal/ index.php?option $=$ com content\&task $=$ view-

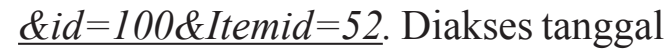
31 maret 2015, pukul 19.47 WIB.

Khaldun, Ibn. The Muqaddimah: An Introduction to History. Terjemahan Franz Rosenthal. London: Routledge \&Kegan Paul, 1967.
Khaldun, Ibn. Muqaddimah Ibn Khaldun. Terjemahan Ahmadi Thoha. Jakarta: Pustaka Firdaus, 2011.

Al-Khudairi, Zainab. Filsafat Sejarah Ibn Khaldun. Bandung: Pustaka, 1995.

Laila Amra. "Ibn Khaldun: Ilmuwan Besar dari Tunisia" dalam http://www.gaulislam.com/Ibn-khaldun-ilmuwanbesar-dari-tunisia.

Quthb, Muhammad. Perlukah Menulis Ulang Sejarah Islam? Jakarta: Gema Insani Press, 1995.

Simon Petrus L.Tjahyadi.Petualangan Intelektual Konfrontasi Dengan Para Filsuf Dari Zaman Yunani Hingga Zaman Modern. Yogyakarta: Kanisius, 2004.

Sivers, P. Von. "Back to Nature: The Agrarian Foundations of Society According to Ibn Khaldun". In Arabica. Vol. 27 No. 1 (1980).

Sorokin, Pitirim A.Sociological Theories of Today. New York and London: Harper \& Row, 1966.

Toto Suharto. Epistemologi Sejarah Kritis Ibnu Khaldun. Yogyakarta: Fajar Pustaka Baru, 2003.

Toynbee, A.J. A Study of Hisatory. 12 Jilid. London: Oxford University Press, 1954.

Wafi, Ali Abdul Wahid. Ibn Khaldun Riwayat dan Karyanya. Terjemahan Ahmadie Thoha. Jakarta: Grafiti Press, 1985. 